Public Policy For Start-up

Entrepreneurship W ith Venture Capital and Bank Finance

Christian Keuschnigg,

IFF-HSG, CEPR and CESifo

Soren Bo Nielsen,

Copenhagen Business School, EPRU, CEPR and CESifo

December 2002 Discussion paper no. 2003-02 
Editor:

Publisher:

Electronic Publication:
Prof. Jörg Baumberger

University of St. G allen

Department of Economics

Bodanstr. 1

CH-9000 St. Gallen

Phone ++41712242241

Fax ++41712242885

Email_joerg.baumberger@unisg.ch

Forschungsgemeinschaft für $\mathrm{N}$ ationalökonomie an der U niversität St. Gallen

Dufourstrasse 48

$\mathrm{CH}-9000$ St. Gallen

Phone $\quad++41712242300$

Fax $\quad++41712242646$

www.fgn.unisg.ch/public/public.htm 


\title{
Public Policy For Start-up Entrepreneurship \\ W ith Venture Capital and Bank Finance
}

\author{
Christian Keuschnigg \\ Soren Bo N ielsen
}
Main Author's address: $\quad$ Prof. Christian Keuschnigg IFF-HSG
Varnbüelstrasse 19
9000 St. G allen
Tel. $\quad++41712242520$
Fax $\quad++41712242670$
Email christian.keuschngg@unisg.ch
W ebsite www.iff.unisg.ch
Co-A uthor's address: $\quad$ Soren Bo $\mathrm{N}$ ielsen
Copenhagen Business School
Solbjerg Plads 3
DK-2000 Frederiksberg, Denmark
Tel. ++45-3815-2596,
Fax: $\quad++45-3815-2576$,
Email: sbn.eco@cbs.dk




\section{Abstract}

This paper proposes and analyses a model of start-up investment. Innovative entrepreneurs are commercially inexperienced and can benefit from venture capital support. 0 nly part of them succeed in matching with a venture capitalist while the rest must resort to standard bank finance. W e consider a number of policies to promote entrepreneurship and venture capital backed innovation.

\section{Keywords}

Venture capital, bank finance, matching, moral hazard, public policy.

\section{JEL Classification}

D 82, G24, G 28, H 24 


\section{Introduction}

Measured as a percentage of GDP, investments in innovative new firms are not large. Neither is the number of technology entrepreneurs. In terms of lending volume, venture capital is no more but a small segment of the financial intermediation sector. However, venture capital backed investment is disproportionately important for economy wide innovation and employment. Kortum and Lerner (2000) calculated that venture capital backed firms account for about 14 percent of industrial innovation in the US in 1998, although they spend only about 3 percent of all research and development funds. Many of today's leading technology firms started out as small venture capital backed companies. It is expected that the most successful of today's ventures will grow rapidly to become key players in important innovation-based industries and be tomorrow's major firms in terms of value creation and jobs. For these reasons, the business community takes great interest in the well-being of entrepreneurial firms. Policy makers likewise worry about the economy's ability to innovate and thereby generate growth and employment.

However, policy makers and businessmen often question whether the business and policy climate is sufficiently conducive to successful innovative activity. Surely, the origin of industrial innovation is basic science. For this reason, venture capitalists and young technology firms tend to be geographically concentrated in major centers of academic and industrial research. Basic research and development, however, is not easily and certainly not automatically translated into commercial success. A policy strategy for innovation based growth must thus address a number of key questions: Are there sufficient incentives for innovators to start their own small technology company? Does tax policy scare away people with business ideas or prevent them from pursuing these ideas in their own company? Are there enough funds available for would-be entrepreneurs?

Young innovative firms need more than just capital. In contrast to their competence in research and development, potential technology entrepreneurs tend to be rather inexperienced in commercial matters. Do entrepreneurs receive enough guidance to successfully develop their ideas into a market success? In short, young technology firms need access 
to informed capital as is provided not by banks but by business angels and venture capital firms with special market knowledge and managerial knowhow. The prime policy question is whether there is any need for government to promote venture capital backed business creation and encourage the activities of venture capitalists beyond what the market achieves on its own.

The public sector is involved in new firms in many ways. Consider the case of Denmark, for illustration. First, basic research in universities and other research centres is almost exclusively publicly funded. To support new firms, a handful of 'technological institutes' have been formed with the aim of extending technical advice to (mostly) new firms. The consulting and advising on the part of these technological institutes is often key in overcoming technical obstacles in further development of prototypes or products. These institutes, however, do not provide managerial support. This is left to business angels and venture capital firms if it happens at all. To foster cooperation between authorities, research centres, universities, technological institutes and firms, seven 'science parks' have been created in Denmark. The transfer of academic knowledge to firms and, thus, the commericalization of science, is the ultimate target of these initiatives.

A public venture capital firm, the Danish Growth Fund, was formed in 1992. It is the major public player in the venture capital business and at the same time an umbrella organization for a series of initiatives towards entrepreneurship. Its official aim is to render the supply of risk capital in Denmark more stable and make it easier for new firms to manage a downturn in the economy. Its initial capital was 2 bill. DKK (a bit less than 300 mill. Euro) which was placed in bonds. The bond return is available for investments in new firms. The private venture capital activity is notoriously difficult to portray statistically. In Denmark, the funds flowing into venture capital come from several sources. Around one tenth is public funds, primarily from the Danish Growth Fund. According to available data, these primarily go into early-stage financing (seed or start-up) whereas other funds, notably from institutional investors and corporate venture firms, are concentrated in later 
(expansion) stages. ${ }^{1}$ In addition to funding early stage firms, the Growth Fund has set up the so-called 'Growth Collateral' initiative which shares credit risk with banks in lending to small firms. Some 'innovation companies' have been established jointly with private investors to promote innovation in high-tech start-ups. The Growth Fund has also issued guarantees to certain 'development companies' that specialize in small and medium-sized enterprises. Finally, it has set up 'innovation environments' often near science parks. These innovation environments can provide pre-project capital and office space and foster cooperation with (private) venture capitalists.

Outside of The Growth Fund, public funds have been injected into a 'Mezzanine Capital Company' (MCC). Mezzanine capital stands for a hybrid of debt and equity capital. The enterprise receiving capital is forced to incorporate. No ceding of control and no collateral is requested and the interest on the capital injection is set to be a function of company income. Alongside public capital, there are also private funds in the MCC. A so-called 'Danish Authorized Market Place' has been set up, too. This is intended to organize an alternative market for shares in non-traded companies and so facilitate further expansion of new companies.

Are conditions for setting up new innovative firms in Denmark satisfactory? Recently, the leading Danish business newspaper postulated:" "Denmark needs more business angels. Persons who are ready to not only extend risk capital but also put forth an effort in those start-ups who will be the 'gazelles' of the future and create value in Danish business." The article further stressed that it is necessary to alleviate the tax burden on Danes so that they will be able to save more and either start a new business themselves or become business angels.

In this context business angels are representative of all types of agents that are able to provide informed early-stage capital to new businesses. At later stages, bank owned

\footnotetext{
${ }^{1} \mathrm{~A}$ recent report finds that 12 pct. of venture capital funds come from public sources. The Danish Growth Fund is the main contributor with 9.8 pct. Note, however, that the Danish Growth Fund and other public sources stand for 54 pct. of seed investments. See The Danish Growth Fund (2002).

${ }^{2}$ Editorial column in Boersen, September 19, 2002, p. 2.
} 
private equity companies are ready to take over successful young businesses and 'package' them for institutional investors. Although The Danish Growth Fund (2002) reports that total seed investments in Denmark have gone up by 180 pct. from 2000 to 2001, the predominant view seems to be that early-stage venture capital financing is still too scarce. Based on a series of interviews conducted last year with support from the Danish Growth Fund with the players in the business (venture capitalists and advisors), Jensen and Vintergaard (2002) identified further possible barriers to entrepreneurship in Denmark. The economic downturn and, in particular, the drop in share prices, were considered a special obstacle. Further, the observers pointed to a lacking entrepreneurial culture and too few business plans together with too little publicly funded (basic) research. Lastly, the structure of personal taxation and the tax treatment of stock options were listed as factors constituting a barrier to entrepreneurship.

The general downturn in the world economy over the last couple of years is hardly something that public innovation policy can remedy. ${ }^{3}$ The other determinants of innovative activity such as the extent of basic research, public consulting, training and advising activity, public funding of early-stage businesses, and tax policy obviously are in the realm of political decisions. They match a series of often-voiced arguments for public interference: the public good character and positive spillovers of research and development, the dissemination of technological knowledge (special institutions, networks), lacking risk capital, lacking incentives for self-employed entrepreneurship, lacking incentives of entrepreneurs in further expansion of the firm, and lacking incentives for close involvement of informed financiers in their portfolio companies.

This paper discusses some key policy strategies towards the creation of innovative businesses. We aim to understand the mechanisms which determine overall entrepreneurship as well as the degree of involvement of venture capitalists. The framework of analysis is a simple setting in which a smaller part of entrepreneurs obtain financing and support from

\footnotetext{
${ }^{3}$ Fortunately, the most recent information emerging from a conference on opportunities for business angels in Denmark underscores that the slowdown has not extinguished entrepreneurship. There are still many refreshing business ideas, although information technology now is a notable exception.
} 
venture capitalists while the remaining majority must resort to standard bank finance. In particular, our framework includes the stylized fact that venture capital backed firms clearly outperform other start-ups that rely on passive bank financing only. We assume that venture capital backed start-ups, when successful, produce and sell goods of higher quality and thereby significantly earn more than other bank financed firms. This premium reflects the value added of venture capital over bank finance.

The empirical evidence is quite clear on this. In comparing venture and non-venture capital backed firms, Brav and Gompers (1997) document that the latter firms generally underperform relative to the former in the longer run. Hellmann and Puri (2002) show that venture capital backed start-ups in Silicon Valley are much faster in introducing stock option plans for skilled personnel and in hiring a professional sales manager. Also, the presence of a venture capitalist makes it more likely that the entrepreneur is replaced by a professional CEO from outside if her lack of managerial abilities turns out to be an impediment to the firm's rapid growth. The venture capitalist's influence is particularly strong in the early phase of business development but is considerably less visible once the firm has successfully matured. In short, venture capitalists add value in promoting the professionalization of young firms. Hellmann and Puri (2000) further show that venture capital backed firms introduce more radical innovations and pursue more aggressive market strategies compared to other start-ups. For example, once a venture capitalist joins the firm and provides finance, the probability of introducing the new product on the market jumps up by a factor of more than three. Rapid market introduction is strategically important because the first firm in the market enjoys a first mover advantage. Kortum and Lerner (2000) similarly show that a Dollar of research and development in firms with venture capital support creates more patents and more radical innovations than the same expenditure in other firms. This empirical evidence clearly supports the notion that venture capital significantly promotes innovation and business growth.

The success of venture capital cannot be taken for granted, however. Although the volume of funds raised and invested grew dramatically in the late 90s, the market is still 
much smaller in Europe. A recent empirical study by Bottazzi and Da Rin (2002) investigated the performance of firms introduced on the European technology stock markets Euro.nm and found that venture capital backed firms have not grown significantly faster and have not performed better than other firms. They conclude that the quality of investments in Europe is a more urgent problem than the sheer volume of funds invested. Is this evidence a reflection of market failure? In our framework, and in line with the above cited empirical evidence, not only the entrepreneur but also the venture capitalist must put up effort to advance the firm's prospects. Since both inputs are largely intangible and not verifyable, the relation between an entrepreneur and a venture capitalist easily suffers from so-called double moral hazard. Accordingly, the equity shares must be carefully split to set incentives for both parties. When both parties must share the marginal return while each one bears the entire marginal cost of extra effort, a natural incentive problem arises. In particular, we expect a bias towards low managerial support on the part of venture capitalists. The industry has developed sophisticated financial instruments such as convertible securities and allocation of control rights that might help to alleviate such incentive problems. ${ }^{4}$ However, as long as both parties must simultaneously supply a joint effort, the two-sided moral hazard will not disappear completely. How is it then possible to strengthen the incentives of venture capital firms to support and advise their portfolio companies more intensively?

Another impediment to the development of a vibrant venture capital industry might be thin market externalities. In the real world, the linking of informed capital and people with business ideas is far from a simple process. Since entrepreneurs and financiers must very closely cooperate once they enter a relationship, each side should be selecting very carefully among the potential candidates. This suggests a costly search effort on both sides. $^{5}$ In our framework, we therefore think of the contact between entrepreneurs and venture capitalists as resulting from a matching process. Accordingly, only a minority of entrepreneurs succeed in being matched with venture capital. The remainder must rely

\footnotetext{
${ }^{4}$ See, for example, Schmidt (2002) for such an argument.

${ }^{5}$ Screening is as important as financial contracting and advice, see Kaplan and Strömberg (2001).
} 
on bank finance or return to employment in industry. The matching process might result in another distortion that could justify a policy intervention. This argument, however, does not automatically create a case for subsidizing the industry. If the bargaining power is distributed among entrepreneurs and venture capitalists in line with their effectiveness in generating a match, the search equilibrium is actually efficient. ${ }^{6}$ However, if the venture capitalist's bargaining position is too weak relative to the entrepreur's position, then her search effort will be inefficiently low, and she will tend to an overly small number of portfolio companies. Her search effort should then be encouraged by appropriate tax incentives or subsidies. The converse holds if she is endowed with an overly strong bargaining position.

While both types of distortions, in principle, call for policy intervention to improve upon the private venture capital equilibrium, the information requirements for the government are quite formidable. It is thus admitted that these insights do not readily translate into practical policy prescriptions that could be made dependant on easily identified market conditions. Nevertheless, we consider it an informative exercise to check the welfare consequences of some of the often proposed policy initiatives within our framework of venture capital backed investment. The literature has largely neglected an explicit policy analysis of venture capital. The few contributions that do exist in this area are not based on a formal principal agent model of venture capital that pays due respect to the incentive problems in this business. ${ }^{7}$ However, we draw upon and extend our own recent work on tax policy towards venture capital by introducing a search model of venture capital finance and allowing for the simultaneous existence of bank and venture capital backed entrepreneurs. ${ }^{8}$ Within this extended framework, we investigate the effects of directly productive government activities as well as taxes and subsidies on the quality and quantity of start-up entrepreneurship in industry equilibrium. In particular, we

\footnotetext{
${ }^{6}$ The matching (in-)efficiency has been quite intensively discussed in the labor market literature, see Hosios (1990) for the key contribution and Boone and Bovenberg (2002) for a recent optimal taxation analysis with search frictions.

${ }^{7}$ See, for example, Poterba (1989a,b), Gordon (1998) and Gompers and Lerner (1998).

${ }^{8}$ See Keuschnigg (2002c) and Keuschnigg and Nielsen (2001a,b, 2002).
} 
consider a government stimulus to basic research to expand the supply of potential technology entrepreneurs, government training of start-up entrepreneurs, subsidies to physical investment cost, and capital gains taxation.

The paper now proceeds in section 2 by giving a general overview of our analytical framework. Section 3 turns to the discussion of a series of policy experiments. Section 4 concludes. The presentation of the model is largely informal. The main purpose of this paper is to highlight the key economic insights and policy implications. We refer the more formally interested reader to a separate mathematical appendix.

\section{A Framework of Analysis}

\subsection{The Market Structure}

Our analysis starts with the presumption that venture capital (VC) is a rather scarce resource and is specialized in financing innovative start-up firms with high potential but high risk. That VCs are in fixed supply reflects the notion that VC finance requires unique investment skills that reflect detailed industry knowledge, personal managerial experience and a good reputation. Such skills cannot be acquired in short order. It takes years to develop the specialized knowhow and experience and the reputation needed for successful coaching of young firms. For this reason, even in the innovation-based industries only a minority of firms are able to attract VC while the majority must rely on standard bank finance. How the market is split between $\mathrm{VC}$ and bank financed firms, is an important but relatively little explored question. ${ }^{9}$ According to our own approach, all technology entrepreneurs favor VC finance because it adds value. Given the limited number of VC firms, entrepreneurs are thus rationed in their access to VC. The probability of locating

\footnotetext{
${ }^{9}$ The discussion in Black and Gilson (1998) is mainly about the relative advantages of a stock market centered or bank centered financial system for the development of a venture capital industry but does not explain how the market for start-up finance is shared among banks and VCs. See Dietz (2002), Strobel (2002) and Ueda (2002) for alternative approaches to market segmentation.
} 
a willing VC reflects the degree of market tightness. Access to VC finance is thus seen as the outcome of a search and matching process. Building on our own previous work in Keuschnigg and Nielsen (2002), we extend the recent work of Inderst and Müller (2002) and Michelacci and Suarez (2002) on the allocation of informed capital in a search market but we additionally introduce bank finance. This paper only sketches the model with an overwiew given in Box 1 and focuses mainly on the policy implications. ${ }^{10}$

To reflect the stylized facts, our framework divides the economy into two sectors, a large traditional and a small innovative, entrepreneurial sector. Production in the traditional sector poses no special problems and risks. Production in the innovative sector takes a business idea with a highly uncertain outcome. Since entrepreneurs are wealth constrained, start-up firms require external finance to further develop new ideas. If they mature to production stage, they supply innovative goods to the market. There are $\bar{E}$ potential technology entrepreneurs who are endowed with a promising yet untested business idea. Only a minor part $E$ of them succeeds to attract venture capital and receives value enhancing managerial advice that helps them to earn a premium on the market. Another part $B$ of start-ups resorts to standard bank finance while the rest, $\bar{E}-E-B$ of them, after an initial attempt to entrepreneurship, returns to employment in the traditional sector. This (large) rest of the economy produces a standard good and absorbs all other economic activity.

At all stages of start-up investment, entrepreneurs may always give up and return to safe employment in the 'old economy'. Taking account of her outside option, a potential entrepreneur faces the following sequence of decisions. First, since VC backed firms yield the greatest reward, all of the entrepreneurs invest a search effort $k$ to achieve contact with one of the F VCs (informed Financiers). Second, if this attempt fails, they either resort to standard bank finance or else return to employment at wage $W$. Bank finance is merely passive and does not include any special managerial support. Banks do not have the required knowhow. Third, if an entrepreneur is matched with a VC, they bar-

\footnotetext{
${ }^{10}$ A separate mathematical appendix with full analytical details is available upon request.
} 
gain over a contract where the $\mathrm{VC}$ buys a share $1-s$ in the firm at a price that covers the start-up investment cost plus an upfront compensation to the entrepreneur. Fourth, given the incentives determined by the contract, both entrepreneur and $\mathrm{VC}$ put in a joint effort to develop the firm to production stage. The VC's effort is oriented to commercial aspects that help to earn a premium over the standard quality of bank financed firms while the entrepreneur's effort aims at a high survival chance. Finally, after success or failure is realized, income is determined and agents spend it on consumption. Demand for innovative goods determines the size of the market for start-up entrepreneurship. Box 1 gives more details.

\section{Box 1: The Formal Framework}

Demand: Following the principle of backward induction, we discuss the decisions in reverse order. Agents spend income $y^{i}$ on traditional and innovative goods, $X^{i}$ and $G^{i}=q C^{E i}+C^{i}$. Except for a quality difference of $q>1$, the quantities $C^{E i}$ and $C^{i}$ supplied by $\mathrm{VC}$ and bank financed firms are perfectly substitutable. Given the quality difference, a VC backed firm earns a premium $q$ over the price $V$ paid for a standard quality of the innovative good. Prices are thus linked by $V^{E}=q V$. Total expenditure is $V^{E} C^{E i}+V C^{i}=G^{i} V$. With effort $l^{i}$ already sunk, the consumption problem is formulated as

$$
U^{i *}=\max _{C^{i}, C^{E i}, X^{i}}\left\{u\left(G^{i}\right)+X^{i}-l^{i} \quad \text { s.t. } \quad X^{i}+V G^{i} \leq y^{i}\right\}
$$

Bank Finance: We consider the entrepreneurs' effort as critical for the success of a start-up firm. It may be either high, $e=1$, or low, $e=0$. In writing the firm's success probability as $e \cdot p_{0}$, we assume that the firm always fails if the entrepreneur shirks. Only high effort retains a positive success probability but implies an effort cost $\beta$. We further assume that entrepreneurs are risk neutral. Under bank finance, her problem is to maximize expected profit $\pi^{B}=e p_{0}(V-D)+\bar{w} \geq \beta e+W$ subject to the bank's break even condition $e p_{0} D \geq I+\bar{w}$ and the incentive constraint $p_{0}(V-D)-\beta \geq 0$. Given that entrepreneurs have no own wealth, start-up investment cost $I$ and any non-performance-related base salary $\bar{w}$ must be financed with 
a credit. Since there is no revenue in case of failure, competitive banks will accept and break even on a minimum expected repayment of $p_{0} D=I+\bar{w}$. The maximum base salary follows from the fact that the incentive constraint limits the maximum credit repayment such that high effort is assured: $p_{0}(V-D)-\beta=0$. High effort raises the success rate from zero to $p_{0}$. The incentive constraint says that the reward for high effort net of effort $\operatorname{cost} \beta$ must be at least as good as the benefit from low effort $(e=0)$. Substituting the bank's break even condition, and anticipating that free entry eliminates any excess surplus over outside wage income $W$, a bank financed entrepreneur's expected profits amounts to

$$
\pi^{B}=p_{0} V-I=\beta+W
$$

Venture Capital Finance: The key distinction to bank finance is that VCs add value to the firm. VC advisory effort $a$ contributes to higher quality, allowing the firm to earn a premium $q(a)>1$ over the general market price $V, q^{\prime}>0>q^{\prime \prime}$. Banks simply do not have the knowhow for value enhancing consulting. Advice comes at an intangible managerial effort cost $\gamma a$. The financial contract must now include incentives for both inputs to the firm's success which requires, in our simple setting, a straight equity contract. The VC's willingness to contribute consulting effort increases with her share $1-s$ in the upside potential of the firm. Since both agents add value, they both have bargaining power and must agree on a mutually satisfactory deal. Since the entrepreneur has no own money, the VC must pay for all start-up cost plus an upfront payment $\bar{w}^{E}$ to the entrepreneur in exchange for a share $1-s$ in the firm. The entrepreneur will be interested in VC finance only if it yields a surplus over the next best mode of finance, $\pi^{E}-\beta \geq \pi^{B}-\beta$, where the same effort cost must be spent unter both alternatives and $\pi^{B}-\beta \geq W$ already compensates for the forgone wage opportunities. The financier's expected profit must reward for her managerial effort cost:

$$
\begin{aligned}
\pi^{E} & =s p_{0} q(a) V+\bar{w}^{E} \geq \pi^{B}, \\
\pi^{F} & =(1-s) p_{0} q(a) V-I-\bar{w}^{E} \geq \gamma a, \\
\chi & =p_{0} q(a) V-I-\gamma a-\pi^{B} .
\end{aligned}
$$

The joint surplus of the venture amounts to $\chi=\pi^{E}-\pi^{B}+\pi^{F}-\gamma a$ and is shared by the two partners. When the $\mathrm{VC}$ and entrepreneur agree on a share $s$ and an upfront payment $\bar{w}^{E}$, these become fixed and determine incentives at effort stage. They must anticipate these incentives 
when bargaining over a deal. Given the VC's bargaining power of $\xi$, their problem is

$$
\begin{aligned}
& \max _{s, \bar{w}^{E}, e, a}\left(\pi^{E}-\pi^{B}\right)^{1-\xi} \cdot\left(\pi^{F}-\gamma a\right)^{\xi} \quad \text { s.t. } \\
& I C^{E}: \operatorname{sp}_{0} q(a) V \geq \beta, \quad I C^{F}:(1-s) p_{0} q^{\prime}(a) V=\gamma .
\end{aligned}
$$

It is in the joint interest to maximize the cake by chosing a share $s$ before distributing it by means of an upfront payment $\bar{w}^{E}$. Once the contract is fixed, the $\mathrm{VC}$ compares her marginal effort cost $\gamma$ with the marginal benefit which is her share in the extra value created, and chooses advice accordingly. Managerial advice and joint surplus increase with the VC's share $1-s$. It is thus in the mutual interest to agree on the lowest possible share $s$ that just suffices to guarantee the entrepreneur's high effort ( $I C^{E}$ becomes binding). With profit sharing thus determined, bargaining fixes the size of the upfront payment and, thereby, splits the joint surplus according to bargaining power, $\pi^{E}-\pi^{B}=(1-\xi) \chi$ and $\pi^{F}-\gamma a=\xi \chi$.

Search For a Deal: A fixed number of $F$ VCs and $\bar{E}$ potential entrepreneurs search for a deal. Allowing for an endogenous search intensity of VCs, they post a total of $v F$ financing offers. The number of random matchings is the mass $E$ of $\mathrm{VC}$ backed firms and depends on equilibrium market tightness $\theta$,

$$
E=f(\theta) v F, \quad \theta \equiv \bar{E} / v F, \quad f^{\prime}(\theta)>0
$$

The number of portfolio firms per $\mathrm{VC}, f(\theta) v$, results from search intensity $v$ and matching probability $f(\theta)$ which is the fraction of financing offers $v F$ leading to a successful deal.

The matching probabilities determine incentives to participate in the search market for VC. A potential technology entrepreneur locates a suitable VC offer only with probability $f(\theta) / \theta$ and then negotiates a share $1-\xi$ of the joint surplus $\chi$. She will search for VC only if the expected gain over bank finance at least covers the search effort cost $k{ }^{11}$

$$
\frac{f(\theta)}{\theta} \cdot(1-\xi) \chi \geq k, \quad f(\theta) \cdot \xi \chi=\delta^{\prime}\left(v_{i}\right)
$$

In making $v_{i}$ offers, an individual $\mathrm{VC}$ expects to realize $v_{i} f(\theta)$ deals where each deal yields a share $\xi$ of the joint surplus $\chi$. Maximizing her expected surplus net of search effort costs,

\footnotetext{
${ }^{11}$ When an E considers entrepreneurship, she first decides whether to search for a VC or directly contact a bank. She searches, if $f / \theta \cdot \pi^{E}+(1-f / \theta) \cdot \pi^{B}-k \geq \pi^{B}$ holds which is the stated condition.
} 
$v_{i} f(\theta) \cdot \xi \chi-\delta\left(v_{i}\right)$, yields the condition in (6). Given that innovative business ideas are scarce, i.e. in fixed supply $\bar{E}$, entrepreneurs derive a rent as indicated by the first inequality which they can appropriate only by searching for a VC.

Among all potential entrepreneurs, a part $\bar{E}$ locates a VC offer while the other part $\bar{E}-E$ either resorts to bank finance or returns to employment at a wage $W$. If it succeeds, a firm produces one unit of output but nothing if it fails. The aggregate quantity supplied is, thus, $p_{0}(B+E)$. Taking account of the quality difference $q$ as in (1), the number $B$ of bank financed entrepreneurs follows from the market clearing condition for innovative goods,

$$
G(V)=p_{0} B+q(a) p_{0} E .
$$

Competitive Search Equilibrium: We assume that there are more 'residual' entrepreneurs willing to start a bank financed firm than what is needed to supply the market that is left over by VC backed firms, i.e. $\bar{E}-E>B$. Free entry thus eliminates profits of bank financed firms and, thereby, fixes the break even price as in (2). ${ }^{12}$ The venture return $V$ sets incentives for effort in VC firms and thereby fixes managerial advice and value maximizing equity sharing as in (4) and the joint surplus of a VC backed firm as in (3). Since $v$ and $\theta$ are uniquely related as in (5), the VCs' search condition in (6) solves for search intensity, market tightness, and equilibrium VC portfolio size $v f(\theta)$. Given the fixed number of VCs, individual portfolio size implies the number of $\mathrm{VC}$ backed firms by the matching condition in (5). The model solution is complete by noting that the zero profits price implies market size and residually determines the number of bank financed start-ups in (7).

We believe that this framework captures the most important stylized facts about the real effects of VC in industry equilibrium. It is worth repeating some key features of our model. In line with empirical evidence, VCs help with managerial advice and thereby importantly promote the professionalization of their portfolio companies. This input is

\footnotetext{
${ }^{12}$ In the traditional sector, one unit of labor produces one unit of output which sells at a price normalized to unity. The wage is thus $W=1$ in competitive equilibrium.
} 
valuable to start-up firms since entrepreneurs often start out being rather inexperienced in matters of business conduct. The value added derived from managerial advice makes VC backed firms more profitable than other ones. For this reason, VC yields a surplus over the next best mode of finance. Since both partners provide a valuable input to the firm, each one has bargaining power that determines how they split this surplus among them. Via bargaining, entrepreneurs can share in the surplus. For this reason, all technology entrepreneurs in our framework prefer VC finance over bank credit and must be rationed due to the limited supply of VC. Depending on the degree of market tightness, only part of the entrepreneurs manage to get matched with a VC.

With VC finance, the success of the firm becomes a function of both the entrepreneur's own critical effort and the VC's contribution and is subject to a double sided moral hazard, given the non-observability of either effort. To provide incentives for both entrepreneurial effort and VC involvement, however, not only the entrepreneur but also the VC must share in the upside potential of the firm. For this reason, an equity contract with proportional profit sharing becomes optimal in our simple framework. By way of contrast, banks are not endowed with entrepreneurial knowhow and cannot add value to the firm beyond the mere financing of start-up cost. With bank finance, the firm's success depends exclusively on the entrepreneur's effort alone. With one-sided moral hazard, the entrepreneur should be full residual claimant on the marginal return to effort which makes straight debt finance the optimal mode of finance.

\subsection{Adding Public Policy}

The proposed framework allows for a rigorous analysis of several policy instruments that are often considered important for the development and maturation of the VC industry. It is mentioned that VC can flourish only in an active research environment. Furthermore, the VC community often complains about a lack of high quality entrepreneurs with promising ideas. This notion also seems to be supported by the fact that in reality, a large part of funds raised is actually not invested but remains idle, waiting presumably 
for more promising investment opportunities. A strengthening of publicly funded basic research can be thought of as increasing the number of potential technology entrepreneurs with a business idea, denoted by $\bar{E}$ in our model. Surely, the strengthening of basic research does not come for free but carries a marginal budget cost of, say, $J^{\prime}(\bar{E})$. What amount of additional resources is warranted to increase the supply of potential technology entrepreneurs must, in principle, be determined in a comparison of the possible benefits and the cost of educating them. For simplicity, we will assume that lump-sum taxes are available to finance the outlays for additional basic research.

Another possible policy initiative is entrepreneurial training and other government sponsored consulting and advising activities vis-a-vis new firms. Such activity aims at raising the survival probability of young entrepreneurial firms. The success probability $p_{0}=p(g)$ would then increase with the outlay $g$ per trained entrepreneur. Since such training generally occurs prior to bank or VC financing, it does not discriminate among financing modes and covers all entrepreneurs.

A third option is to subsidize the physical investment cost which must be incurrred to start a firm. An investment subsidy reduces the private cost of start-up investment to $(1-z) I$. In principle, the subsidy can distinguish between bank and VC financed firms $\left(z^{E}\right.$ and $\left.z^{F}\right)$. It is given irrespective of whether the firm succeeds or not. It thus captures most of the real world policy initiatives to promote business creation which primarily subsidize start-up (financing) costs. In practice, governments mostly hand out interest subsidies, direct government loans at reduced interest cost, or credit guarantees that help to reduce the bank's risk premium on small business loans. We consider how this subsidy fares in our more explicit model of $\mathrm{VC}$ and bank finance.

Since young, fast growing firms are unable to pay dividends, the return on such investment almost exclusively accrues as capital gains to the initial investment, both to entrepreneurs and financiers. The business community considers the capital gains tax as the most important tax barrier, and policy makers have often proposed to cut capital gains taxes to stimulate start-up investment of innovative firms. To the best of our 
knowledge, and except for our own earlier attempts, this tax has not yet been subject to a rigorous analysis within a structural model of $\mathrm{VC}$ finance that allows to capture the incentive effects for the joint effort of entrepreneurs and VCs. ${ }^{13}$

\section{Policy Analysis}

A rigorous policy analysis must first answer the question whether there is any useful role at all for the government in correcting certain market distortions and market failures. In view of the fact that government activity itself often suffers from regulatory capture as Lerner (2002) emphasizes in the context of innovation finance, such market distortions must be clearly identified to warrant any specific subsidies, tax breaks or other expenditure in favor of the industry. Our model of the VC industry allows for several potentially useful policy initiatives. First, there might be a potential role for specific tax breaks or direct subsidies to address certain market distortions. And second, there might exist a directly value enhancing government activity that is not substituted easily by the private sector. To characterize the optimal policy towards VC in our framework, we first derive the socially optimal resource allocation which follows from maximizing an aggregate welfare measure subject to resource and technological constraints. ${ }^{14}$ Comparing this optimal allocation with the competitive market equilibrium, we can identify potential distortions and their

\footnotetext{
${ }^{13}$ See the references to the public finance literature in the introduction. However, Inderst and Mueller (2002) shortly discuss the capital gains tax. It is not their main focus, however, and a rigorous welfare based analysis is missing.

${ }^{14}$ The welfare measure derives from aggregating individual welfare as in equation (1) of Box 1:

$$
U^{*}=L-(I+g)(E+B)+u(G)-\beta(E+B)-\gamma a E-\delta(v) F-k \bar{E}-J(\bar{E})
$$

Supply of the traditional good amounts to $L=1-E-B$, the labor input of the non-entrepreneurial population. Start-up investment in the innovative sector absorbs a quantity $(I+g)(E+B)$ which leaves a welfare of $L-(I+g)(E+B)$ from consumption of this good. The supply and consumption of the innovative good amounts to $G$, yielding welfare $u(G)$, from which one must substract all relevant effort costs plus the resource cost $J(\bar{E})$ of educating potential entrepreneurs via basic research expenditure.
} 
remedies via public policy initiatives.

\subsection{Potential Distortions}

Our framework points to two potential distortions in VC finance where tax policy might help to improve private incentives. The first one derives from the fact that the success of a $\mathrm{VC}$ backed firm requires the joint effort of both the entrepreneur and financier and is therefore subject to a double moral hazard problem. The VC contract must provide incentives for both parties to secure their joint effort. For this reason, not only the entrepreneur but also the $\mathrm{VC}$ must share in the upside potential of the venture which makes an equity contract with profit sharing preferable to straight debt finance. Profit sharing, however, cannot deliver the right incentives for a socially optimal effort. While both the entrepreneur and the VC must fully bear their private effort cost, the return to one's own effort must be shared with the partner of the venture under an equity contract with proportional profit sharing. ${ }^{15}$ When an agent appropriates only part of the return on extra effort but must bear the full cost, her effort tends to be inefficiently low. In our framework, we have treated the entrepreneur's effort as absolutely critical for the success of the firm and have assumed it to be either high or low. Since shirking makes the firm fail with certainty, the parties will thus always agree on a minimal profit share that just suffices to secure the entrepreneur's full effort. The problem thus remains with the VC's managerial support. ${ }^{16}$ The need to share the return on effort with the entrepreneur installs a bias towards inefficiently low VC support. Policy should target the VCs' incentives for closer involvement with their portfolio companies.

Before drawing any immediate policy conclusions, however, one should emphasize that the industry has partly developed its own solutions to at least alleviate the problem.

\footnotetext{
${ }^{15}$ This is evident from equation (4) in Box 1.

${ }^{16}$ The revised version of Keuschnigg and Nielsen (2002) treats both efforts as variable. In consequence, not only the VC's but also the entrepreneur's input tends to be underprovided. Discrete effort on the part of the entrepreneur considerably simplifies the analysis and does not change our conclusions with respect to the VCs' behavior.
} 
Schmidt (2002), among others, has shown that the use of convertible securities which are prevalent in $\mathrm{VC}$ finance can go a long way to allocate the right incentives at the right time to each partner. Stage financing, i.e. the tying of further financing rounds to the achievement of predefined milestones in the company's development, also addresses the problem. However, as long as both inputs must be supplied simultaneously at least in some stages of the firm's development, as we assume in our framework, the inefficiency problem never fully disappears.

A second potential distortion relates to the search effort for a $\mathrm{VC}$ deal. A successful deal for a new $\mathrm{VC}$ investment generates a surplus that is divided among the $\mathrm{VC}$ and the entrepreneur according to their bargaining power. Before this surplus becomes available, both parties must search in the matching market for a suitable partner. The private search intensity of a VC compares the search cost incurred by posting another financing offer with the expected return to search. The expected gain consists of the probability of finding a promising venture times the VC's share in the surplus as in equation (6) of Box 1. The matching probability is determined in equilibrium and is an increasing function of market tightness, the ratio of potential entrepreneurs looking for a deal to the number of outstanding financing offers by VCs. The more entrepreneurs there are relative to the total number of outstanding financing offers, the easier it is for a VC to find a suitable investment project when she decides to post an additional financing offer. The matching equilibrium in the market for $\mathrm{VC}$ is efficient only if the effectiveness of $\mathrm{VC}$ search in generating a deal (as measured by the elasticity $\eta$ of the number of successful matches with respect to financing offers) exactly corresponds to the VC's bargaining power $\xi$ in splitting the joint surplus. This is the so-called Hosios (1990) condition for an efficient search equilibrium.

One can understand the balance of ex-post bargaining power with the matching effectiveness as a condition for the efficient distribution of property rights over the returns to search. The search effort is a specific investment in a future relationship between an entrepreneur and a VC. These specific investments cannot be contracted because the en- 
trepreneur and $\mathrm{VC}$ do not know at this stage the identity of their future business partner after matching. They meet only after they have sunk their search cost, i.e. their specific investment in the relationship. The efficiency condition $\xi=\eta$ implies that the party that carries out the most important non-contractible investments should be most powerful ex post so that it can correspondingly claim most of the rents. ${ }^{17}$ A distortion arises whenever the condition is violated. When entrepreneurs have excessive bargaining power relative to their matching effectiveness, the search effort of VCs is discouraged. The scarcety of financing offers results in an overly small number of deals. Each VC firm ends up with an inefficiently small portfolio of firms. VC investments should be encouraged by strengthening the VC's search incentives. The opposite conclusions hold if VCs instead of entrepreneurs have overly high bargaining power. However, since the extent of each party's bargaining power is not easily determined, it seems difficult to delineate practical policy guidelines. For this reason, we henceforth concentrate more on the case of efficient search (with $\xi=\eta)$.

\subsection{Optimal Policy Towards Venture Capital}

Starting from the presumption that VCs should be involved more intensively in their portfolio companies to attain a higher quality of VC, policy must either address marginal benefits or costs of an extra managerial input. Since effort cost is intangible in nature and therefore cannot be the target of tax policy, one is left with a revenue subsidy to VC backed companies. The purpose of this subsidy is to make the VC the full residual claimant on the return to her effort as is required for efficiency. ${ }^{18}$ This revenue subsidy given to portfolio firms, however, not only strengthens incentives for advice and thereby improves the quality of VC financing, it also stimulates the quantity of VC investments. In making VC investments privately more profitable, it leads VCs to search more intensively

\footnotetext{
${ }^{17}$ See Boone and Bovenberg (2002) for an analogous interpretation of the Hosios condition in the context of labor market search.

${ }^{18}$ In equation (4), the revenue subsidy $\tau<0$ is set such that $(1-\tau)(1-s)=1$. With this subsidy in place, the VC would appropriate the full social gains $p_{0} q^{\prime}(a) V$ of her consulting effort.
} 
for new deals. If the search equilibrium in the market for $\mathrm{VC}$ is efficient because the VCs' bargaining power is well aligned with their effectiveness in generating deals, such extra stimulus for more VC investments would be counterproductive. In our framework of the $\mathrm{VC}$ industry, more quality but not more quantity of $\mathrm{VC}$ finance is needed. Therefore, the optimal policy is to combine a revenue subsidy that encourages managerial support, with a tax (rather than a subsidy) on start-up investment cost. The purpose of this tax is to offset the incentive for increased entry which is created by the advice enhancing revenue subsidy. Note that a tax on physical investment cost is not harmful to the incentives for advice since this cost is already sunk when managerial effort must be expended.

With this package, the policy can largely be self-financing. In fact, if the matching equilibrium is efficient, search should neither be encouraged nor discouraged. In this case, the revenue subsidy cum investment tax is exactly self-financing in our framework. The optimal policy changes, however, if the search effort is distorted because of excessive bargaining power of VCs. If VCs are able to appropriate a disproportionately large share of the joint surplus, they will chase new deals with a search intensity higher than what is warranted by their effectiveness in generating deals. This tendency for overinvestment in terms of VC quantity, or number of portfolio companies financed, could be offset with an even higher investment tax. The opposite conclusion holds if the VCs' bargaining power were smaller than what is required for an efficient distribution of property rights on the returns to search.

None of these considerations applies to bank financed firms. There is neither any role for a revenue subsidy since banks to not offer advice, nor a subsidy or tax on start-up investment cost since there are no search-related distortions. Bank lending is passive without any relationship-specific investments and thus fully competitive in our framework. In assuming uniform ability of entrepreneurs, we have however excluded any issue of adverse selection which might potentially justify certain policy interventions. Both overlending and rationing of bank financing are potential outcomes, depending on how returns and 
risk are determined by entrepreneurial ability. ${ }^{19}$ We have abstracted from such issues and therefore cannot identify any role for specific policies directed towards bank lending.

Governments often assume an active role in supporting start-up entrepreneurs. Entrepreneurial training, government consulting and similar other activities are meant to raise the survival chances of young firms. These measures typically do not distinguish between bank and VC financed firms. Suppose the government spends resources $g \cdot(E+B)$, or $g$ per trained entrepreneur. A marginal increase in spending enables the entrepreneur to succeed with an increased probability $p_{0}^{\prime}(g)$ and thereby raises expected revenues of the firm. Entrepreneurial training is a publicly supplied private good much like any other education expenditure. Being excludable, it is possible without problem to charge a user fee. Presumably, such expenditure simply substitutes for private activity, at least to some extent. As it turns out, optimal policy fully charges entrepreneurs for the training cost. The level of the training activity is optimally expanded until the marginal expected output gains from raising the success rate, valued at the price of innovative goods, equals the marginal resource cost $E+G$ of doing so. ${ }^{20}$

Finally, it is often claimed that a vibrant VC industry can develop only in an active research environment. Proponents of the $\mathrm{VC}$ community also complain that there is a lack of technology entrepreneurs. More spending on basic research can help to increase the supply of potential technology entrepreneurs. Often, public funds are allocated to fields of research that lend themselves more easily for commercialization and where the expenditure is more likely to result in start-ups and spin-offs. Furthermore, governments often encourage the commercialization of research quite explicitly in building business incubators and providing other business related infrastructure near universities or other research

\footnotetext{
${ }^{19}$ See De Meza (2002) for a discussion.

${ }^{20}$ Maximizing aggregate welfare $U^{*}=u(G)-(I+g)(E+B)+\ldots$ yields an optimality condition $(q E+B) V \cdot p_{0}^{\prime}(g)=E+B$ where $V=u^{\prime}(G)$ and $G=q E+B$ is used. The same condition would obtain if firms could buy such services on a competitive market. Bank-financed firms would maximize $\pi^{B}=p_{0}(V-D)-g+\bar{w}$ and buy until $p_{0}^{\prime}(g) V=1$ or $B \cdot p_{0}^{\prime}(g) V=B$ in the aggregate, and similarly for VC-financed firms. Our framework does not explain why such a market solution should fail.
} 
centers, hoping that this will encourage a larger number of would-be entrepreneurs. We capture this in our framework in an admittedly crude way by postulating that the fixed supply $\bar{E}$ of potential technology entrepreneurs can be increased with additional basic research spending at a progressively increasing budget cost of $J(\bar{E}) .{ }^{21}$

The optimal amount of spending is arrived at when the marginal resource cost $J^{\prime}(\bar{E})$ of educating another potential technology entrepreneur is balanced by the expected marginal income gain thus created. Since the supply of potential technology entrepreneurs $\bar{E}$, by assumption, can be expanded only with additional public spending on basic research, entrepreneurs derive a private rent as indicated by the inequality in (6) of Box 1 . If the search equilibrium is efficient, i.e. $\xi=\eta$, then the private rent corresponds to the net gain to society, net of search effort, of having an additional candidate for a VC backed start-up firm. The marginal cost of educating this extra technology entrepreneur is $J^{\prime}(\bar{E})$. In the social optimum, the rent to entrepreneurship is balanced by marginal expenditure. ${ }^{22}$ Although this is a somewhat crude modeling, it does point to the fact that public spending directed towards the commercialization of science and the education of potential technology entrepreneurs must ultimately by justified by the extra income or surplus it creates in equilibrium.

\subsection{The Effects of Policy Reform}

Considerations of optimal policy design are seldom easily translated into practical tax policy. In this section, we consider small policy changes. ${ }^{23}$ The appendix repeats in (A.1) those equations of Box 1 that change in the presence of taxes. We first turn to the capital gains tax which is considered one of the most important tax barriers to the development

\footnotetext{
${ }^{21}$ That basic research expands the supply of technology entrepreneurs is surely more a beneficial side effect rather than the main purpose of such spending. One might therefore wish to interpret $J$ as that part of research spending which specifically aims at generating a higher probability of spin-offs.

${ }^{22}$ The optimality condition is $f(\theta) / \theta \cdot(1-\eta) \chi-k=J^{\prime}(\bar{E})$.

${ }^{23}$ To keep calculations simple, we start from an untaxed equilibrium position. See the appendix for analytical results on comparative statics.
} 
of the $\mathrm{VC}$ industry.

Capital Gains Taxation: Since young firms hardly pay any dividends, the return on such firms accrues mostly as capital gains over any initial equity investment. This applies to both bank financed and VC backed companies. A competitive industry with free entry cannot sustain pure profits over the long-run. The free entry condition for bank financed firms thus fixes the equilibrium return $V$ allowing firms to break even. Venture returns must compensate for all relevant costs but no more than that. Given entrepreneurs require a fixed compensation for their effort cost and the foregone wage income, venture returns must increase so that expected capital gains net of the tax still suffice to cover the opportunity cost. A higher price of innovative goods squeezes market size and should thus lead to exit.

One can expect further interesting implications for market structure. Higher venture returns strengthen incentives for effort, in particular the incentives for the VCs' managerial consulting. On the other hand, the capital gains tax itself rather directly discourages managerial support as it reduces the private return on extra effort. ${ }^{24}$ On net, VC backed firms will receive less managerial support. When VCs become less involved, the market orientation of firms will suffer, leading to lower innovation and quality improvements and, in turn, to a lower market premium. Consequently, the performance of VC backed relative to bank financed firms will be less impressive. The financial contract, in addition, includes an upfront payment to the entrepreneur which splits the joint surplus among the two parties. The tax squeezes this shared surplus as a net result of three effects: first, the tax directly takes away from the surplus. Second, it discourages advice and thus diminishes the value added by the VC. And third, as a partially offsetting effect, the tax raises the competitive price, as part of the firms leave the industry. The net effect is negative, see equations (A.4-6) in the appendix.

\footnotetext{
${ }^{24}$ See (A.2-3). Since the entrepreneur's effort is critical, it must alsways be high. If her return on effort is reduced on account of the tax and the decline in the VC's value added contribution, she must be allocated a higher equity share to retain her critical effort.
} 
The lower joint surplus of VC backed firms is shared among entrepreneurs and VCs and thus determines their incentives to search for a deal. It is said that VCs often consider up to 100 business plans but in the end finance only about 5 out of them. According to our framework, a VC searches for a deal by posting a larger number of financing offers. Depending on market tightness, she is able to strike a deal only on a fraction of them and ends up with a much smaller portfolio of firms, see equation (5) in Box 1. The desired search intensity and, thus, her portfolio size is achieved if the marginal effort cost of searching for another deal is equal to expected profits which is the probability of striking a deal times her share in the joint surplus of the firm, see (6). Obviously, if the capital gains tax diminishes the shared surplus of VC backed firms, it thereby reduces search effort. Consequently, each VC will end up with a smaller portfolio. Given the fixed number of VCs, the number of VC backed start-up firms must decline, see (A.7) of the appendix. The capital gains tax thus reduces not only the quality, but also the quantity of VC backed investments in our framework.

We can now consider the equilibrium impact on the number of bank financed entrepreneurs. Since the tax requires a higher price of innovative goods to allow bank financed firms to break even, market size in (7) of Box 1 must shrink. Since the quality adjusted supply of VC backed firms declines, there is in principle an ambiguity in the effect on the number of bank financed firms. If the market share of $\mathrm{VC}$ backed firms is small at the outset, however, the decline in market size surely dominates and forces bank financed firms to leave the industry. Even though we consider only a small tax increase, we expect a first order welfare loss. If the search equilibrium is efficient, there are no welfare consequences from a change in market tightness. ${ }^{25}$ In the preceding subsections, we have identified a distortion with respect to the extent of $\mathrm{VC}$ involvement in their portfolio companies and have shown that managerial advice is inefficiently low in the market equilibrium. Since the capital gains tax further discourages advice which is already too low at the outset, it entails a first order welfare loss. For this reason, the capital gains tax

\footnotetext{
${ }^{25}$ Search efficiency holds for $\xi=\eta$, eliminating the effect of market tigthness $\theta$ in (A.11).
} 
is particularly harmful to the industry. Previous contributions have pointed out that the capital gains tax impairs VC investments. However, none of these analyses have actually derived their predictions based on a structural model of the $\mathrm{VC}$ industry that pays due attention to the incentive problems emphasized in the finance literature.

Subsidizing Start-up Investment Cost: The investment subsidies work somewhat differently. A subsidy to bank financed firms allows for a decline in the competitive industry price and thereby expands the market for innovative goods. Since the subsidy is already sunk at effort stage, it involves no direct effect on effort. Note, however, that the competitive reduction in venture returns impairs incentives for advice. Via this general equilibrium effect, VC involvement in portfolio companies must suffer. Somewhat astonishingly, the investment subsidy which also applies to VC backed firms, actually reduces joint surplus. While the direct effect of the subsidy is to raise private values, see (A.4), the diminshed value added in terms of $\mathrm{VC}$ support and the lower equilibrium price dominate and render the total effect on joint surplus negative. Consequently, VCs are less eager to search for more deals. As market tightness rises, fewer entrepreneurs succeed to attract VC finance. While there are fewer VC backed firms, the number of bank financed companies strongly expands. Not only is market size larger, but also a smaller market share is taken up by VC backed firms, see (A.8). A uniform subsidy that indiscriminately subsidizes start-up investment by both types of firms, ends up forcing VC backed firms out of business while strongly expanding the number of bank financed firms.

The picture might change if policy succeeds to limit the investment subsidy to VC backed firms only. In this case, there would be no effect on the equilibrium price since bank financed firms are not directly affected. Neither would this subsidy affect incentives for managerial advice. The joint surplus would simply increase by the extent of the subsidy without any further effects, see (A.4). Consequently, VCs would start to search more intensively so that the market becomes less tight and more technology entrepreneurs succeed to locate a VC. With market size and VC induced product quality unchanged in (7), the additional VC backed firms simply crowd out bank financed firms. Welfare should 
not change much. If the search market is efficient, market tightness is without impact on welfare. Further, there is no first order welfare gain or loss from the adjustment in advice simply because the subsidy has no influence on advice.

\section{Conclusions}

In virtually all industrial countries, the public sector is engaged in promoting in innovation and entrepreneurship in many ways. Taking Denmark as an example, we reported a number of public policy initiatives ranging from stimulating basic research in institutions of higher education to direct public venture capital support for start-ups. In between, entrepreneurial training and government consulting, favorable depreciation rules for research and development, and tax policy targeted towards young technology firms are also expected to promote entrepreneurship in innovative industries. We have introduced a formal framework for the analysis of the effects of basic research, government training and advising of business starters, selected subsidies, and capital gains taxes. We demonstrated the potential of these policies to promote start-up entrepreneurship in innovative industries and welfare. In particular, we have discussed the differential effects on bank financed and venture capital backed firms in industry equilibrium.

Despite its importance to policy makers, a model-based analysis of public policy towards start-up entrepreneurship in innovation-based industries is largely missing. Our attempt in this direction may be considered too simple with respect to some aspects of the industry. We have indeed abstracted from a number of potentially important aspects of venture capital finance. To keep the analysis tractable, we have, for example, taken the entrepreneurial effort to be all or nothing while in reality the trade-off is surely not that stark so that effort should better be considered a continuous variable. ${ }^{26}$ Furthermore, we considered the fate of start-up firms to be either a complete failure or a success

\footnotetext{
${ }^{26}$ In Keuschnigg and Nielsen (2002), however, we analyze the double moral hazard problem with continuous efforts by both VCs and entrepreneurs. On the other hand, the simultaneous existence of bank and $\mathrm{VC}$ financed firms is ignored.
} 
with no outcome in between. In reality, even failures generate some value and success comes to a variable extent, ranging from 'living dead' to high-flyers. We have considered entrepreneurs to be identical while in the real world entrepreneurial ability, again, varies considerably. Indeed, one of the main functions of informed capital is to pick the more able among all entrepreneurs under conditions of limited information (screening). The presence of adverse selection is indeed expected to change the interaction of banks and venture capitalists in financing young firms. Finally, the dynamics of entrepreneurship (staging) and the complexity of financial contracting was relatively neglected in our analysis. All these issues are highly relevant, but also very difficult if at the same time the real effects in industry equilibrium must be determined. We must leave these extensions for future research.

\section{Appendix}

This appendix derives some key comparative static results of changes in the uniform capital gains $\operatorname{tax} \tau$ and an investment subsidy $z$ (negative values indicate a subsidy). It is further assumed that the entrepreneur's base salary or upfront payment $\bar{w}$ is taxed at the same rate $\tau$. Under this assumption, (A.1) restates those equations of Box 1 which change in the presence of taxes:

$$
\begin{aligned}
& \pi^{B}=(1-\tau)\left[p_{0} V-(1-z) I\right], \quad \pi^{B}-\beta=W, \\
& \pi^{E}=(1-\tau)\left[s p_{0} q(a) V+\bar{w}^{E}\right] \geq \pi^{B}, \\
& \pi^{F}=(1-\tau)\left[(1-s) p_{0} q(a) V-(1-z) I-\bar{w}^{E}\right] \geq \gamma a, \\
& \chi=(1-\tau)\left[p_{0} q(a) V-(1-z) I\right]-\gamma a-\pi^{B}, \\
& \left(4^{\prime}\right) I C^{E}:(1-\tau) s p_{0} q(a) V \geq \beta, \\
& \left(4^{\prime}\right) I C^{F}:(1-\tau)(1-s) p_{0} q^{\prime}(a) V=\gamma \text {. }
\end{aligned}
$$

We consider comparative statics starting from the untaxed position, $\tau=z=0$ initially. In loglinearizing the model at the initial equilibrium position, we define $\hat{\tau} \equiv d \tau /(1-\tau)=$ 
$d \tau$, and $\hat{z} \equiv d z /(1-z)=d z$. The equilibrium price follows from free entry in bank financed projects, $\pi^{B}=p_{0} V-I=1+\beta$ with $W=1$ by normalization. Using (2'),

$$
\hat{V}=\frac{1+\beta}{p_{0} V} \hat{\tau}-\frac{I}{p_{0} V} \hat{z} \Rightarrow \hat{V}-\hat{\tau}=-\frac{I}{p_{0} V}(\hat{\tau}+\hat{z}) .
$$

The tax and the investment subsidy both affect the equilibrium price of a standardquality innovative good. To calculate the effect on advice and profit sharing, log-linearize the twin conditions in $\left(4^{\prime}\right)$ and find the simultaneous solution. Assuming $q(a)=(1+a)^{\alpha}$, $0<\alpha<1$, and defining $\hat{a}=d a /(1+a)$, one obtains $\hat{q}=\alpha \hat{a}$ and $\hat{q}^{\prime}=-(1-\alpha) \hat{a}$. The two linearized incentive constraints (4'), i.e. $(1-\alpha) \hat{a}=\hat{V}-\hat{\tau}-\frac{s}{1-s} \hat{s}$ for the VC and $\hat{s}=-\alpha \hat{a}-\hat{V}+\hat{\tau}$ for the entrepreneur, are then solved to yield

$$
\hat{a}=\frac{1}{1-s-\alpha}(\hat{V}-\hat{\tau}), \quad \hat{s}=-\frac{1-s}{1-s-\alpha}(\hat{V}-\hat{\tau}) .
$$

The capital gains tax discourages advice. The lower venture return also undermines the entrepreneur's incentives so that she requires a higher share $s$ to put up her full effort.

Profits with bank financing are fixed at $\pi^{B}=1+\beta$. The joint surplus of VC backed firms thus changes by $d \chi=p_{0} q V \hat{V}+I \hat{z}-\left(p_{0} q V-I\right) \hat{\tau}+\left(p_{0} q^{\prime} V-\gamma\right)(1+a) \hat{a}$. Substituting $I C^{F}$ for $\gamma$, and using $(1+a) q^{\prime} / q=\alpha$, we have $\left(p_{0} q^{\prime} V-\gamma\right)(1+a)=s p_{0} q V \alpha$, which gives

$$
\hat{\chi} \equiv \frac{d \chi}{p_{0} q V}=\hat{V}+\frac{I}{p_{0} q V} \hat{z}-\left(1-\frac{I}{p_{0} q V}\right) \hat{\tau}+s \alpha \hat{a} .
$$

The investment subsidy raises joint surplus. The tax works via three channels. The direct impact of the tax is negative. Further, the tax discourages advice and thereby also erodes joint surplus. Finally, by raising the price of standard quality due to taxation of bank financed firms, the tax actually tends to boost joint surplus. Substituting (A.3), the net effect is

$$
\hat{\chi}=\Psi \hat{V}+\frac{I}{p_{0} q V} \hat{z}-\left(\Psi-\frac{I}{p_{0} q V}\right) \hat{\tau}, \quad \Psi \equiv \frac{(1-s)(1-\alpha)}{1-s-\alpha}>1 .
$$

Note that $\Psi>1$ is a multiplier such that the effects via advice strengthen the direct effects of the tax and the price. For this reason, $\Psi-I / p_{0} q V$ is unambiguously positive. Substituting (A.2), and using (2') which is $\pi^{B}=p_{0} V-I=1+\beta$ in the untaxed 
equilibrium,

$$
\hat{\chi}=-\frac{(q \Psi-1) I}{p_{0} q V}(\hat{\tau}+\hat{z}) .
$$

Policy affects the supply of VC because VCs share in the higher joint surplus which makes them search more intensively for investments. Defining the elasticity of marginal search effort cost, $\varepsilon \equiv v \delta^{\prime \prime} / \delta^{\prime}$, and noting the matching elasticity $\theta f^{\prime} / f=1-\eta$ and the link between the number of financing offers and markte tightness, $\hat{\theta}=-\hat{v}$, the search condition (6) yields

$$
\hat{\theta}=-\frac{1}{1-\eta+\varepsilon} \hat{\chi}, \quad \hat{E}=-\eta \hat{\theta}=\frac{\eta}{1-\eta+\varepsilon} \hat{\chi}
$$

The second condition comes from the matching equilibrium condition in (5) of Box 1.

Finally, the equilibrium number of bank financed start-ups follows from (7) of Box 1. Given a demand elasticity $\mu,{ }^{27}$ we have [note $\left.G=q p_{0} E+p_{0} B\right]$

$$
\hat{G}=-\mu \hat{V}=\phi(\alpha \hat{a}+\hat{E})+(1-\phi) \hat{B}, \quad \phi \equiv q E p_{0} / G
$$

where $\phi$ is the market share of $\mathrm{VC}$ backed firms, as measured in overall quality units. Substituting preceeding results into $(1-\phi) \hat{B}=-\mu \hat{V}-\phi(\alpha \hat{a}+\hat{E})$ yields, after some manipulations,

$$
\begin{aligned}
(1-\phi) \hat{B} & =-\frac{p_{0} V-I}{p_{0} V} \mu \hat{\tau}+\phi \Omega \frac{I}{p_{0} q V} \hat{\tau}+(\mu q+\phi \Omega) \frac{I}{p_{0} q V} \hat{z}, \\
\Omega & \equiv \frac{\alpha q}{1-s-\alpha}+\frac{(\Psi q-1) \eta}{1-\eta+\varepsilon} .
\end{aligned}
$$

There is some ambiguity in the effect of the tax rate. But as long as the share $\phi$ of VC financed firms is small, the tax entails the normal effect of driving bank financed entrepreneurs out of business.

Welfare: Aggregating individual welfare in (1) over $L$ workers, $E$ VC backed and $B$ bank financed entrepreneurs yields $U^{*}=C S+Y-\beta(E+B)-\gamma a E-\delta(v) F-k \bar{E}$ with

\footnotetext{
${ }^{27}$ The optimality condition to $(1), u^{\prime}(G)=V$, implies an elasticity $\mu=-u^{\prime}(G) /\left[G u^{\prime \prime}(G)\right]$.
} 
consumer surplus $C S=u(G)-G V$. Substitute income $Y=L+\left(\pi^{E}+\pi^{F}\right) E+\pi^{B} B$, use $L=1-E-B$, exploit the free entry condition $\pi^{B}=1+\beta$, and use $\chi=\pi^{E}-\pi^{B}+\pi^{F}-\gamma a$ :

$$
U^{*}=C S+1+\chi E-\delta(v) F-k \bar{E} .
$$

Upon linearization, taking $\bar{E}$ and $F$ as fixed, using $\delta^{\prime}=f \xi \chi$ and $E=f \cdot v F$ from (5-6), as well as $\hat{E}=-\eta \hat{\theta}, \hat{v}=-\hat{\theta}$ and $d C S=-G V \hat{V}$, one obtains

$$
d U^{*}=-G V \hat{V}+\chi E \hat{\chi}+(\xi-\eta) \cdot \chi E \hat{\theta} .
$$

The last term vanishes if search equilibrium is efficient, $\xi=\eta$.

\section{References}

[1] Aghion, Philippe and Peter Howitt (1998), Endogenous Growth Theory, Cambridge: MIT Press.

[2] Black, Bernard S. and Ronald J. Gilson (1998), Venture Capital and the Structure of Capital Markets: Banks Versus Stock Markets, Journal of Financial Economics 47, 243-277.

[3] Boone, Jan and Lans Bovenberg (2002), Optimal Labour Taxation and Search, Journal of Public Economics 85, 53-97.

[4] Bottazzi, Laura and Marco Da Rin (2002), Venture Capital in Europe and the Financing of Innovative Companies, Economic Policy 34, 231-269.

[5] Brav, Alon and Paul A. Gompers (1997), Myth or Reality? The Long-Run Underperformance of Initial Public Offerings: Evidence From Venture and Nonventure Capital Backed Companies, Journal of Finance 52, 1791-1821.

[6] The Danish Growth Fund (2002), Det danske marked for venture kapital og private equity (The Danish Market for Venture Capital and Private Equity), Copenhagen.

[7] De Meza, David (2002), Overlending?, Economic Journal 112, F17-F31.

[8] Diamond, Peter (1990), Pairwise Credit in Search Equilibrium, Quarterly Journal of Economics 105, 285-319.

[9] Dietz, Martin D. (2002), Risk, Self Selection, and Advice: Banks versus Venture Capitalists, University of St.Gallen, IFF WP No. 0201. 
[10] Gompers, Paul A. and Josh P. Lerner (1998), What Drives Venture Capital Fundraising?, Brookings Papers on Economic Activity - Microeconomics, 149-192.

[11] Gordon, Roger H. (1998), Can High Personal Tax Rates Encourage Entrepreneurial Activity?, IMF Staff Papers 45, 49-80.

[12] Grossman, Gene M. and Elhanan Helpman (1991), Innovation and Growth in the Global Economy, Cambridge: MIT Press.

[13] Hellmann, Thomas and Manju Puri (2000), The Interaction Between Product Market and Financing Strategy: The Role of Venture Capital, Review of Financial Studies 13, 995-984.

[14] Hellmann, Thomas and Manju Puri (2002), Venture Capital and the Professionalization of Start-Up Firms, Journal of Finance 57, 169-197.

[15] Hosios, Arthur J. (1990), On the Efficiency of Matching and Related Models of Search and Unemployment, Review of Economic Studies 57, 279-298.

[16] Inderst, Roman and Holger M. Müller (2002), Venture Capital Contracts and Market Structure, CEPR DP. 3203.

[17] Jensen, Nikolaj W. and Christian Vintergaard (2002), Vaekstfremmende faktorer for den danske venturekapitalbranche (Growth Enhancing Factors for the Danish Venture Capital Industry), MPP Working Paper, Copenhagen Business School.

[18] Kanniainen, Vesa and Christian Keuschnigg (2001), Start-up Investment With Scarce Venture Capital Support, CESifo WP No. 381, revised.

[19] Kaplan, Steven N. and Per Strömberg (2001), Venture Capitalists as Principals: Contracting, Screening, and Monitoring, American Economic Review 91, 426-430.

[20] Keuschnigg, Christian (2002a), Finanzpolitik, Unternehmensgründungen und Sucharbeitslosigkeit, in: Bernd Genser (ed.), Finanzpolitik und Arbeitsmärkte, Schriften des Vereins für Socialpolitik, N.F. 289, Berlin: Duncker and Humbolt, $45-82$.

[21] Keuschnigg, Christian (2002b), Venture Capital Backed Growth, CESifo DP 664.

[22] Keuschnigg, Christian (2002c), Taxation of a Venture Capitalist With a Portfolio of Firms, CESifo DP 813.

[23] Keuschnigg, Christian and Soren B. Nielsen (2002), Start-ups, Venture Capitalists and the Capital Gains Tax, CESifo DP 742, revised.

[24] Keuschnigg, Christian and Soren B. Nielsen (2001a), Tax Policy, Venture Capital and Entrepreneurship, Journal of Public Economics, forthcoming. 
[25] Keuschnigg, Christian and Soren B. Nielsen (2001b), Public Policy for Venture Capital, International Tax and Public Finance 8, 557-572.

[26] Kortum, Samuel and Josh P. Lerner (2000), Assessing the Contribution of Venture Capital to Innovation, Rand Journal of Economics 31, 674-692.

[27] Lerner, Josh P. (2002), When Bureaucrates Meet Entrepreneurs: The Design of Effective 'Public Venture Capital' Programmes, Economic Journal 112, 557-572.

[28] Michelacci, Claudio and Javier Suarez (2002), Business Creation and the Stock Market, CEPR DP 3513.

[29] Poterba, James M. (1989a), Capital Gains Tax Policy Toward Entrepreneurship, National Tax Journal 42, 375-389.

[30] Poterba, James M. (1989b), Venture Capital and Capital Gains Taxation, in: Lawrence, H.S. (eds), Tax Policy and the Economy, Vol. 3, Cambridge: MIT Press, 47-67.

[31] Romer, Paul (1997), Growth Based on Increasing Returns Due to Specialization, American Economic Review 77, 56-63.

[32] Schmidt, Klaus M. (2002), Convertible Securities and Venture Capital Finance, Journal of Finance, forthcoming.

[33] Strobel, Peter (2002), Marktsegmentierung zwischen Venture Capital und Banken (Market Segmentation Between Venture Capital and Banks), unpublished dissertation thesis, University of Saarland.

[34] Ueda, Masako (2002), Bank Versus Venture Capital, Universitat Pompeu Fabra, Discussion Paper.

[35] Wasmer, Etienne and Philippe Weil (2000), The Macroeconomics of Labor and Credit Market Imperfections, Bonn: IZA DP 179. 